\title{
Antitumor effects of a dual-specific lentiviral vector carrying the Escherichia coli purine nucleoside phosphorylase gene
}

\author{
XIAOLONG WANG ${ }^{1}$, LEI SUN $^{2}$, XUEJUN SUN $^{3}$, JUNHUI YU $^{3}$,

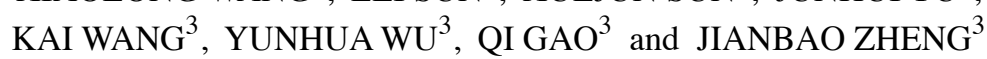 \\ Departments of ${ }^{1}$ Oncology and ${ }^{2}$ General Surgery, The Second Affiliated Hospital \\ of Xi'an Jiaotong University, Xi'an, Shaanxi 710004; ${ }^{3}$ Department of General Surgery, \\ The First Affiliated Hospital of Xi'an Jiaotong University, Xi'an, Shaanxi 710061, P.R. China
}

Received January 18, 2017; Accepted March 13, 2017

DOI: 10.3892/ijo.2017.3949

\begin{abstract}
The Escherichia coli purine nucleoside phosphorylase/Fludarabine phosphate (ePNP/Fludara) suicide system has several drawbacks, such as side-effects and the low efficiency of ePNP expression. In this study, we evaluated the antitumor effects of the dual-specific 8HSEs-hTERTpePNP/Fludara suicide system under hyperthermia in vitro and in vivo. Luciferase activities from the 8HSEs-hTERT and CMV promoters were compared using the dual luciferase assay in SW480 (high hTERT expression) and MKN74 cells (hTERT-negative) in the presence and absence of hyperthermia. Then, we investigated the effects of overexpressing the suicide gene ePNP using 8HSEs-hTERT-driven lentiviral vectors with Fludara on in vitro cell viability, side-effects, apoptosis, cycle distribution, colony formation and in vivo xenograft tumor growth. At $43^{\circ} \mathrm{C}$, luciferase activity from the 8HSEs-hTERT promoter was significantly increased in SW480 cells, but not in MKN74 cells. Importantly, luciferase activities from the 8HSEs-hTERT promoter were much higher than from the CMV promoter in hTERT-expressing SW480 cells under heated conditions. The in vitro quantitative analysis showed a 4-fold higher ePNP protein expression from the 8 HSEs-hTERT promoter at $43^{\circ} \mathrm{C}$ than at $37^{\circ} \mathrm{C}$ in SW480 cells and the ePNP mRNA expression in SW480 cells at $43^{\circ} \mathrm{C}$ was also higher than at $37^{\circ} \mathrm{C}$. Conversely, ePNP mRNA and protein expression were low, almost absent, in hTERT-negative MKN74 cells with or without hyperthermia. After Fludara addition, cell cytotoxicity assays showed that the significant inhibitory effect of the 8HSEs-hTERTp-ePNP on SW480
\end{abstract}

Correspondence to: Professor Xuejun Sun or Dr Jianbao Zheng, Department of General Surgery, The First Affiliated Hospital of Xi'an Jiaotong University, 277 West Yanta Road, Xi'an, Shaanxi 710061, P.R. China

E-mail: sunxysky@163.com

E-mail: bob.zheng@stu.xjtu.edu.cn

Key words: dual-specific, hyperthermia, PNP/Fludara, heat shock element, gene therapy cells was dose- and time-dependent with hyperthermia. The 8HSEs-hTERTp-ePNP/Fludara suicide system significantly inhibited SW480 cell viability, colony formation, cell cycle progression and induced apoptosis in vitro, but also induced significant bystander effects, especially under the heated conditions. At the protein level, the suicide system significantly promoted Bax, caspase- 3 and p53 expression and suppressed Bcl-2 expression. In sections from mouse xenografts, TUNEL assays showed that the suicide system reduced xenograft growth and induced SW480 apoptosis. These results indicated that the combinatorial cancer- and heat-specific promoter system has great potential for improving the efficacy of cancer treatment with hyperthermia. The 8HSEs-hTERTp-ePNP/ Fludara system may serve as a powerful strategy for cancer gene therapy combined with hyperthermia.

\section{Introduction}

The Escherichia coli purine nucleoside phosphorylase/fludarabine (ePNP/Fludara) suicide system, originally described by Sorscher et al (1), has been demonstrated to have powerful killing and bystander effects (2). Differing from human or mammalian PNP, this bacterial PNP enzyme converts the low-toxic prodrug Fludara into a very toxic metabolite, 2-fluoroadenine (F-Ade). F-Ade impairs DNA, RNA and protein synthesis (3), killing both dividing and non-dividing cells. However, several drawbacks to PNP/Fludara suicide system remain to be resolved, including the side-effects and low efficiency of ePNP gene expression.

Hyperthermia, an inducible antitumor treatment, has gained acceptance for cancer therapy in breast and colorectal carcinomas as well as malignant melanomas (4-6). Recent studies have shown that hyperthermia not only sensitizes tumor cells to radiation and chemotherapy, but also activates HSP70 expression in some cells. This makes the combination of hyperthermia and gene therapy possible. Furthermore, hyperthermia can augment the effects of therapeutic genes in a controlled range (7). Hyperthermia-induced HSP70 activation is regulated at the transcriptional level (8) and depends on heat shock elements (HSEs), which are short sequences in the HSP70 promoter that are essential for heat inducibility. The introduction of HSEs into a gene transfer vector makes 
it possible to provide special control over exogenous gene expression in a locally heated tumor (8).

The human telomerase reverse transcriptase (hTERT) promoter has been widely used to drive the specific expression of therapeutic genes for cancer treatment. The hTERT promoter is significantly weaker than many commonly used viral promoters, such as the cytomegalovirus (CMV) early promoter and the simian virus 40 (SV40) early promoter (9). This limitation caused us to hypothesize that the combination of heat shock elements (HSEs) with the hTERT promoter in a recombinant lentiviral vector may significantly increase the transcriptional activity of the hTERT promoter, improving the efficiency of ePNP gene expression in a locally heated tumor.

Therefore, we designed and constructed a recombinant lentiviral vector carrying the ePNP gene under the control of the 8HSEs-hTERT promoter, which ensured targeted and powerful gene expression in tumor cells. We expect that administration of this recombinant lentiviral vector together with the prodrug Fludara could provide a new strategy for clinical therapy of solid tumors together with hyperthermia.

\section{Materials and methods}

Reagents. Fludarabine phosphate (Fludara) was obtained from Sigma-Aldrich (St. Louis, MO, USA) and dissolved in phosphate-buffered saline (PBS). Rabbit monoclonal antibodies specific for Bax, Bcl-2, caspase-3, p53, Fas, cyclin D1 and $\beta$-actin were obtained from Epitomics (Burlingame, CA, USA); rabbit monoclonal antibodies specific for 3FALG were obtained from Sigma-Aldrich. TurboFect ${ }^{\mathrm{TM}}$ transfection reagent was acquired from Thermo Fisher Scientific (Waltham, MA, USA), and Dual-Glo Luciferase assay system from Promega (Madison, WI, USA).

Cell culture and in vitro hyperthermia. Human colorectal cancer SW480 and gastric cancer MKN74 cells were obtained from Shanghai Institute of Cell Biology, Chinese Academy of Sciences (Shanghai, China). SW480 and MKN74 cells were cultured in RPMI-1640 supplemented with $10 \%$ fetal bovine serum (FBS), $100 \mathrm{IU} / \mathrm{ml}$ penicillin, $100 \mathrm{mg} / \mathrm{ml}$ streptomycin and $2 \mathrm{mM} \mathrm{L-glutamine.} \mathrm{Cells} \mathrm{were} \mathrm{grown} \mathrm{at} 37^{\circ} \mathrm{C}$ in a humidified atmosphere containing $5 \% \mathrm{CO}_{2}$. Cells were seeded into cell culture dishes and incubated at $37^{\circ} \mathrm{C}$ for $24 \mathrm{~h}$. Afterwards, cells were transferred to a cell culture incubator that was pre-adjusted to $43^{\circ} \mathrm{C}$ for $1 \mathrm{~h}$ every $48 \mathrm{~h}$ (data not shown) (10). After incubation for the desired time, cells were transferred back to the $37^{\circ} \mathrm{C}$ incubator and incubated for several hours to recover from the heat treatment.

Construction of plasmid vectors. Preparation of plasmids was accomplished using the Omega plasmid midi kit (Omega, Norcross, GA, USA). The 295-bp promoter region (11) of human TERT [GenBank accession no. AN097365] was amplified by PCR from human genomic DNA, using the following primer pairs: TERT promoter (forward, 5'-CTAGCTAGC CACAGACGCCCAGGACCGCGCTTC-3'; reverse, 5'-CCC AAGCTTCCACGTGCGCCCACGTGCGCCCAC-3'. The 295-bp fragment was inserted into pGL4.2 (Promega) upstream of the luciferase reporter gene and verified by DNA sequencing to generate pGL4.2-hTERTp. Eight heat shock elements (8HSEs) with optimized AGAACGTTCTAGAAC sequences $(10,12)$ alternately separated by $5 \mathrm{bp}$ were generated by oligonucleotide ligation. The 8 HSEs fragments were inserted upstream of the luciferase reporter in pGL4.2-hTERTp to generate pGL4.2-8HSEs-hTERTp.

The 588-bp CMV early promoter was amplified by PCR from pLVX-EGFP-3FLAG (GeneChem, Shanghai, China), using the following primer pairs: forward, 5'-CGCCTCGAG CCGCCTGGCTGACCGCCCA-3'; reverse, 5'-GCCAGATCT GCCATGGTTCGAATTCAAAT-3'. The amplified 588-bp fragment was cloned into $\mathrm{pGL}-4.2$ to generate $\mathrm{pGL} 4.2-\mathrm{CMVp}$.

Dual luciferase assay. SW480 and MKN74 cells were seeded 5,000 cells per well into each well of a 96 -well plate. The next day, cells were transfected with 150 ng luciferase reporter plasmid (pGL4.2-8HSEs-hTERTp or pGL4.2-CMVp) and 30 ng of pGL-4.74 (containing the TK promoter; Promega) as an internal control using the TurboFect ${ }^{\mathrm{TM}}$ Transfection reagent (Thermo Fisher Scientific) according to the manufacturer's instructions. After 10-h transfection, the mixture was replaced with fresh medium. After $48 \mathrm{~h}$, cells were subjected to heat treatments. Luciferase assays were performed $6 \mathrm{~h}$ later using the Dual-Glo Luciferase assay system (Promega). Briefly, $100 \mu 1$ of Dual-Glo Luciferase assay reagent was added to each well, followed by the addition of $100 \mu$ l Dual-Glo Stop \& Glo reagent. Renilla luminescence was normalized to the internal control vector pGL-4.74 luminescence. Promoter activities were measured as relative luminescence units (RLU) where the value of the firefly luciferase luminescence of pGL-4.2 was divided by the Renilla luciferase pGL- 4.74 from the same well.

Establishment of stable lentivirus-transfected cell lines. Two recombinant lentiviruses pLVX-8HSEs-hTERTp-ePNP3FLAG (8HhP) and a negative control pLVX-Ubi-3FLAG $(\mathrm{CON})$ containing the ubiquitin promoter were purchased from GeneChem. The recombinant lentiviral vector (pLVX-8HSEs-hTERTp-ePNP-3FLAG) including the hTERT promoter modified by the artificial $8 \mathrm{HSEs}$, the ePNP gene and three consecutive FLAG sequences was constructed using conventional recombinant techniques. SW480 and MKN74 cells were transduced with the $8 \mathrm{HhP}$ and $\mathrm{CON}$ lentiviruses following standard techniques. After $72 \mathrm{~h}$, lentivirus-carrying clones were selected for 15 days in medium containing $1 \mathrm{mg} / \mathrm{ml}$ puromycin (Life Technologies, Grand Island, NY, USA).

Quantitative reverse transcription polymerase chain reaction (qRT-PCR). SW480, MKN74 and the stably transfected SW480-8HhP, SW480-CON, MKN74-8HhP and MKN74-CON cells were subjected to an RNA Fast 200 kit (Pioneer Biotech, Xi'an, China) to isolate total RNA according to the manufacturer's instructions. cDNA was synthesized from $1 \mu \mathrm{g}$ of DNase I-treated total RNAs with PrimeScript ${ }^{\mathrm{TM}} \mathrm{RT}$ Master Mix (Takara, Dalian, China) according to the manufacturer's instructions. An aliquot $(1 \mu \mathrm{l})$ of the cDNA was then subjected to qRT-PCR analysis of ePNP mRNA using SYBR ${ }^{\circledR}$ Premix Ex Taq ${ }^{\mathrm{TM}}$ II (Takara). The primers were as follows: ePNP (product: $64 \mathrm{bp}$ ) forward, 5'-TGGGTCACGGTATGG GTATC-3'; reverse, 5'-CCGAAATCGGTGATCAGTTC-3'. $\beta$-actin (product: $151 \mathrm{bp}$ ) forward, 5'-CTTAGCACCCCTGGC 
CAAG-3'; reverse, 5'-GATGTTCTGGAGAGCCCCG-3'. The ePNP and $\beta$-actin qPCR reaction mixture was denatured at $94^{\circ} \mathrm{C}$ for $3 \mathrm{~min}$ followed by 40 cycles of $94^{\circ} \mathrm{C}$ for $30 \mathrm{sec}, 57^{\circ} \mathrm{C}$ for $30 \mathrm{sec}$, and $72^{\circ} \mathrm{C}$ for $30 \mathrm{sec}$. All reactions were performed in triplicate and the relative ePNP mRNA level in each cell line was calculated by the $2^{-\Delta \Delta \mathrm{Ct}}$ method, where $\Delta \mathrm{Ct}=\mathrm{Ct}(\mathrm{ePNP})$ - Ct ( $\beta$-actin).

Protein extraction and western blots. Cells treated with or without Fludara were lysed on ice with NP-40 buffer containing $40 \mathrm{mM}$ Tris- $\mathrm{HCl}$ (pH 6.9), $2 \mathrm{mM}$ ethylenediaminetetraacetic acid (EDTA, pH 8.0), $100 \mathrm{mM}$ sodium fluoride, $150 \mathrm{mM} \mathrm{NaCl}$, $10 \mathrm{mM}$ sodium pyrophosphate, $1 \%$ Tergitol type NP-40, $2 \mathrm{mM}$ sodium orthovanadate, $1 \%$ Triton X-100, $1.0 \mathrm{mM}$ phenylmethanesulfonyl fluoride (PMSF), and 1X protease inhibitor mini-tablet (Roche, Basel, Switzerland). Lysates were then clarified by centrifugation at $12,000 \mathrm{x}$ g for $10 \mathrm{~min}$ at $4^{\circ} \mathrm{C}$. Protein concentration was estimated using the Pierce Protein Estimation system (Thermo Fisher Scientific) according to the manufacturer's protocol. Next, equal amounts $(30 \mu \mathrm{g})$ of protein were heated at $95^{\circ} \mathrm{C}$ for $5 \mathrm{~min}$ in $5 \mathrm{X}$ Laemmli sample buffer, separated on a 10\% SDS-PAGE gel and transferred onto polyvinylidene difluoride (PVDF) membranes by the wet transfer method. Non-specific binding was blocked for $1 \mathrm{~h}$ at $37^{\circ} \mathrm{C}$ using $10 \%$ fat-free milk in TBS containing $0.1 \%$ Tween-20. The membranes were blotted with anti-Bax, Bcl-2, caspase-3, p53, Fas, cyclin D1, $\beta$-actin or anti-3FALG primary antibodies at a dilution of 1:2,000. After washing three times with TBST, horseradish peroxidase-conjugated secondary antibodies (1:5,000 dilution; Proteintech, Chicago, IL, USA) were added at $27^{\circ} \mathrm{C}$ for $1 \mathrm{~h}$. Immunoreactive bands were visualized using SuperSignal West Femto Maximum Sensitivity Substrate (Thermo Fisher Scientific) and exposed using the ChemiDoc $\mathrm{XRS}^{+}$(Bio-Rad, Hercules, CA, USA).

Cell viability assay. Cell viability was detected using the cell counting kit-8 (CCK-8, Dojindo Molecular Technologies, Inc., Kumamoto, Japan). Briefly, 2,000 parental and stably transduced cells were inoculated into 96 -well plates in a final volume of $200 \mu \mathrm{l}$ growth medium. The hyperthermia group was treated at $43^{\circ} \mathrm{C}$ after $24 \mathrm{~h}$. After treatment and incubation, each plate was subjected to the CCK- 8 assay by adding $10 \mu \mathrm{l}$ of CCK-8 solution to each well, and the plate was further incubated for $2 \mathrm{~h}$ at $37^{\circ} \mathrm{C}$. The absorbance at $450 \mathrm{~nm}$ was measured with an EnSpire ${ }^{\mathrm{TM}}$ Multilabel Reader 2300 (Perkin-Elmer Inc., Waltham, MA, USA). The relative cellular survival rate was calculated using the following formula: $\left(\mathrm{A}_{\text {sample }}-\mathrm{A}_{\text {blank }}\right) /$ $\left(\mathrm{A}_{\text {control }}-\mathrm{A}_{\text {blank }}\right)$ x $100 \%$ (13).

Flow cytometric apoptosis and cell cycle distribution assays. SW480, SW480-8HhP, SW480-CON, MKN74, MKN74-8HhP and MKN74-CON cells were seeded into 6-well plates and the hyperthermia group was treated at $43^{\circ} \mathrm{C}$ for $1 \mathrm{~h}$ every $48 \mathrm{~h}$. For apoptotic analysis, apoptosis detection kit (Becton-Dickinson, Franklin Lakes, NJ, USA) was used to analyze apoptosis rates according to the manufacturer's instructions. For cell cycle analysis, cells growing in logarithmic phase were fixed with $75 \%$ ethanol for $24 \mathrm{~h}$ at $-20^{\circ} \mathrm{C}$, incubated with RNase A and Triton X-100 at $37^{\circ} \mathrm{C}$ for $30 \mathrm{~min}$, and then incubated with propidium iodide at room temperature for $30 \mathrm{~min}$. Cells were examined by flow cytometry, and CellQuest software (Becton-Dickinson) was used to conduct data acquisition and analysis.

Colony formation assay. SW480, SW480-8HhP, SW480-CON, MKN74,MKN74-8HhP and MKN74-CON cells (200 cells/well) were suspended in $2 \mathrm{ml}$ media and seeded into 6-well plates. The hyperthermia group was also treated at $43^{\circ} \mathrm{C}$ for $1 \mathrm{~h}$ every $48 \mathrm{~h}$, after treatment with or without Fludara, cells were fixed and stained with $1 \%$ crystal violet and cell colonies were counted under an inverted microscope. Statistical comparison was conducted using Student's t-test.

In vivo gene expression and analysis of antitumor effects. $\mathrm{BALB} / \mathrm{c}$ nude mice were used according to the guidelines for administration to lab animals, issued by the Ministry of Science and Technology (Beijing, China). Tumors were established by subcutaneous inoculation with SW480 and MKN74 cells (100 $\mu 1$ containing $1 \times 10^{7}$ cells). Tumor volume was calculated using the empirical formula $\mathrm{V}=0.52 \times$ [(shortest diameter $^{2} \mathrm{x}$ (longest diameter)]. When the tumor volume reached $100 \mathrm{~mm}^{3}$, tumor-bearing mice were randomly divided into six groups of 6 mice each: pLVX-Ubi-3FALG+PBS (SW480-CON+PBS), pLVX-Ubi-3FALG+Fludara $+37^{\circ} \mathrm{C}$ (SW480-CON+Fludara $+37^{\circ} \mathrm{C}$ ), pLVX-Ubi-3FALG+Fludara $+43^{\circ} \mathrm{C}$ (SW480-CON+Fludara $+43^{\circ} \mathrm{C}$ ), pLVX-8HSEs-hTERTpePNP-3FALG+PBS (SW480-8HhP+PBS), pLVX-8HS Es-hTERTp-ePNP-3FALG+Fludara $+37^{\circ} \mathrm{C}$ (SW480-8HhP+ Fludara $+37^{\circ} \mathrm{C}$ ) and pLVX-8HSEs-hTERTp-ePNP-3FALG+ Fludara $+43^{\circ} \mathrm{C}\left(\mathrm{SW} 480-8 \mathrm{HhP}+\right.$ Fludara $\left.+43^{\circ} \mathrm{C}\right)$. The mice in each group were intratumorally administered $100 \mu 1$ serum-free medium containing $1 \times 10^{8}$ pfu pLVX-Ubi-3FALG or pLVX8HSEs-hTERTp-ePNP-3FALG. Three days later, lentivirus administration was repeated. Fludara $(10 \mathrm{mg} / \mathrm{kg})$ dissolved in $0.5 \mathrm{ml}$ PBS was injected intraperitoneally three times daily for three consecutive days, beginning $48 \mathrm{~h}$ after the administration of recombinant lentivirus. This schedule was counted as a single course and three consecutive courses were administered (14). On the 11th and 13th day post-inoculation, mice were placed in a $43^{\circ} \mathrm{C}$ water bath for $1 \mathrm{~h}$. The feet of the mice were tied to four nails on a board to ensure the transplanted tumors were immersed in the water bath (10). Tumor size and growth were monitored and measured using a caliper at regular intervals. Mice were sacrificed two weeks after the second virus injection and xenograft tumors were harvested, measured and photographed. Six mice in each group were sacrificed and the tumor specimens were subjected to histopathological analysis and TUNEL staining.

TUNEL assay. Paraffin-embedded tissue slides were prepared from the xenograft tumors. TUNEL staining was detected by the DeadEnd ${ }^{\mathrm{TM}}$ Fluorometric TUNEL system (Promega) according to the manufacturer's instructions. Cells were fixed and permeabilized with PBS containing 4\% paraformaldehyde and $0.25 \%$ Triton X-100. Fluorescence was measured after incubation with FITC-labeled TUNEL. After TUNEL staining, the specimens were immersed with a DAPI solution (Sigma-Aldrich) to stain nuclei. Fluorescence staining was viewed by laser scanning confocal microscopy (FV300, Olympus, Tokyo, Japan) (15). 

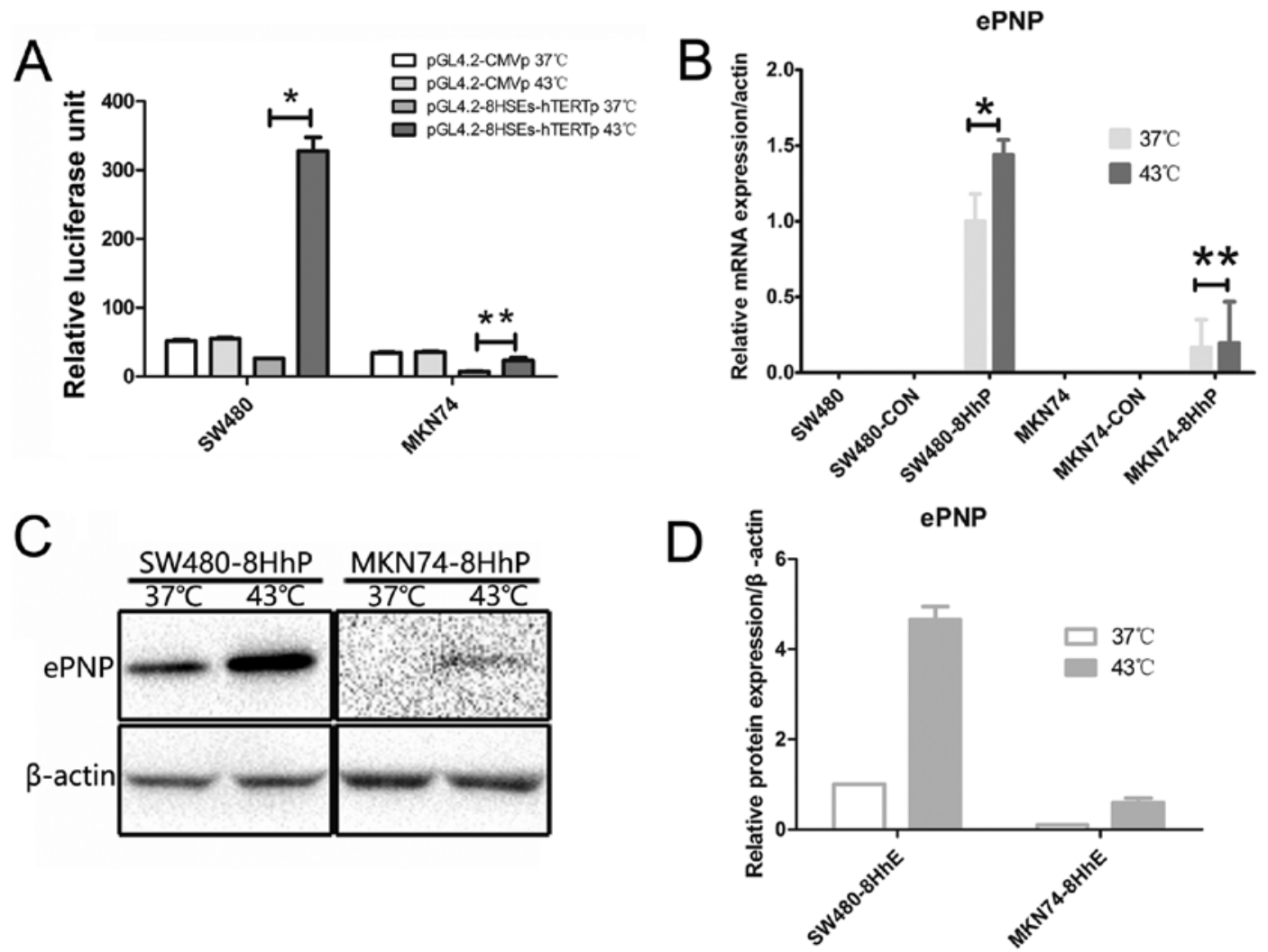

Figure 1. Hyperthermia- and tumor-specificity of the synthetic 8HSEs-hTERT promoter. (A) Luciferase activity from the synthetic 8HSEs-hTERT and CMV promoters at $37^{\circ} \mathrm{C}$ or $43^{\circ} \mathrm{C}$ in SW480 (hTERT-high expressing) and MKN74 cells (hTERT-negative). ${ }^{*} \mathrm{P}<0.05$, pGL4.2-8HSEs-hTERTp $43^{\circ} \mathrm{C}$ vs. pGL4.2-8HSEs-hTERTp $37^{\circ} \mathrm{C}$ in SW480 cells; ${ }^{* *} \mathrm{P}>0.05$, pGL4.2-8HSEs-hTERTp $43^{\circ} \mathrm{C}$ vs. pGL4.2-8HSEs-hTERTp $37^{\circ} \mathrm{C}$ in MKN74 cells. (B) Quantitative PCR analysis of ePNP mRNA expression regulated by the synthetic 8HSEs-hTERT promoter at $37^{\circ} \mathrm{C}$ or $43^{\circ} \mathrm{C}$ in $\mathrm{SW} 480$ cells and MKN74 cells. "P<0.05, $37^{\circ} \mathrm{C}$ vs. $43^{\circ} \mathrm{C}$ in SW $480-8 \mathrm{HhP}$ cells; ${ }^{* *} \mathrm{P}>0.05,37^{\circ} \mathrm{C}$ vs. $43^{\circ} \mathrm{C}$ in MKN74-8HhP cells. (C) Western blot analysis of ePNP expression regulated by the synthetic 8HSEs-hTERT promoter at $37^{\circ} \mathrm{C}$ or $43^{\circ} \mathrm{C}$ in SW480 cells and MKN74 cells. (D) Integrated optical density was measured to evaluate ePNP expression [from $(C)$ ] relative to $\beta$-actin.

Statistical analysis. Results are shown as means \pm standard error. Differences were evaluated with unpaired two-tailed Student's t-tests with unequal variance for multiple comparisons using the SPSS software version 19.0 (SPSS Inc., Chicago, IL, USA). $\mathrm{P}<0.05$ was considered statistically significant. All experiments were independently repeated at least three times.

\section{Results}

Hyperthermia inducibility of the synthetic 8HSEs-hTERT promoter. To determine the hyperthermia inducibility of the synthetic 8HSEs-hTERT promoter after heat treatment, we transfected SW480 and MKN74 with pGL4.2-8HSEs-hTERTp or pGL4.2-CMVp. Transfected cells were incubated at either $43^{\circ} \mathrm{C}$ or $37^{\circ} \mathrm{C}$ for $1 \mathrm{~h}$ and the resultant luciferase activity was measured. Treatment at $43^{\circ} \mathrm{C}$ for $1 \mathrm{~h}$ significantly increased the luciferase activity of SW480 but not MKN74 cells ( $\mathrm{P}<0.05$ and $\mathrm{P}=0.219$, respectively, Fig. 1A). Contrastingly, $43^{\circ} \mathrm{C}$ treatment resulted in no apparent differences in pGL4.2-CMVp luciferase activity among these cell lines. Moreover, after the $43^{\circ} \mathrm{C}$ treatment, the 8HSEs-hTERT promoter luciferase activity was significantly higher than the CMV promoter. These results demonstrated that hyperthermia could significantly enhance the transcriptional activity of the 8HSEs-hTERT promoter in SW480 cells, which endogenously express high hTERT levels.
These data suggested that the 8HSEs-hTERTp promoter might be more efficient and specific than the CMV promoter for tumor targeting with hyperthermia.

Overexpression of ePNP in tumorcells using an $8 H S E s$ - $h T E R T p$ driven expression vector. We tested ePNP expression in hTERThigh expressing SW480 cells and hTERT-negative MKN74 cells (10) using an $8 \mathrm{HSEs}$-hTERTp-driven expression vector at $37^{\circ} \mathrm{C}$ or $43^{\circ} \mathrm{C}$. ePNP expression was confirmed by qRT-PCR and western blotting (Fig. 1B and C) in SW480-8HhP and MKN74-8HhP cells. SW480-8HhP cells showed very high levels of ePNP mRNA at $43^{\circ} \mathrm{C}$ or $37^{\circ} \mathrm{C}$, but MKN74-8HhP only showed low levels of ePNP mRNA at $43^{\circ} \mathrm{C}$ or $37^{\circ} \mathrm{C}$. Similarly, ePNP protein levels were significantly increased in SW480-8HhP cells under heat (Fig. 1D). However, ePNP protein levels were very low at $43^{\circ} \mathrm{C}$ in MKN74-8HhP cells, and almost absent at $37^{\circ} \mathrm{C}$ (Fig. 1C and D). As a heterologous gene, ePNP protein and mRNA were negative in SW480, MKN74, SW480-CON and MKN74-CON cells at $43^{\circ} \mathrm{C}$ or $37^{\circ} \mathrm{C}$. These data indicated that both ePNP mRNA and protein were expressed in hTERT-high expressing SW480-8HhP cells, especially following heat application.

Sensitivity of infected cells to Fludara. To test whether ePNP could sensitize cancer cells to Fludara, we tested the proliferation of the different cell lines using the CCK- 8 method to 

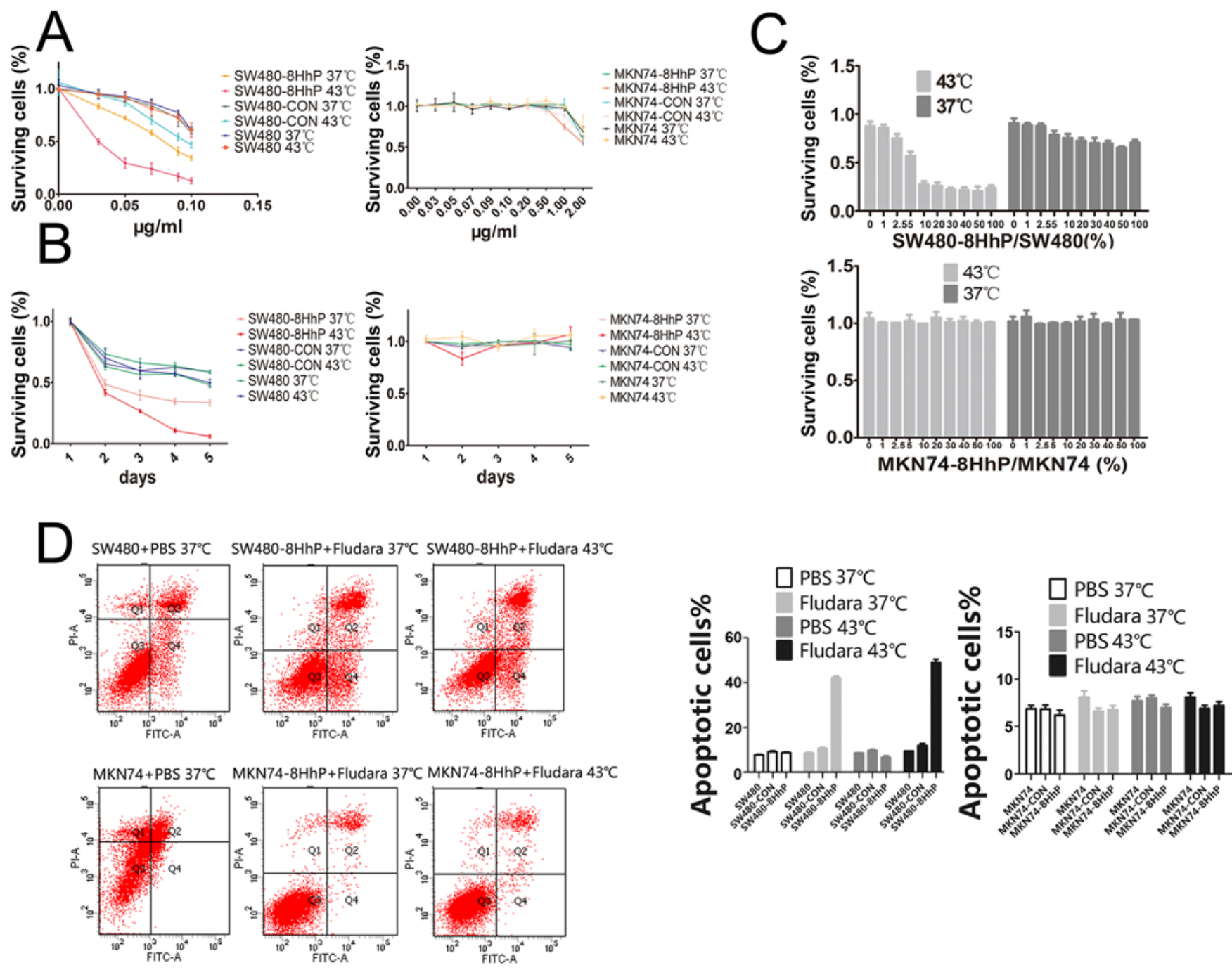

Figure 2. Cytotoxicity of the suicide system ePNP/Fludara regulated by the synthetic 8HSEs-hTERT promoter. (A) Sensitivity of SW480, MKN74 and the corresponding infected cells to Fludara at $37^{\circ} \mathrm{C}$ or $43^{\circ} \mathrm{C}$ by CCK- 8 assay. (B) Growth curves of SW480, MKN74 and the corresponding infected cells to Fludara at $37^{\circ} \mathrm{C}$ or $43^{\circ} \mathrm{C}$ by CCK-8 assay. (C) Bystander effect of SW480, MKN74 and the corresponding infected cells to Fludara at $37^{\circ} \mathrm{C}$ or $43^{\circ} \mathrm{C}$ by CCK- 8 assay. (D) Apoptosis rates of SW480, MKN74 and the corresponding infected cells to Fludara at $37^{\circ} \mathrm{C}$ or $43^{\circ} \mathrm{C}$ by flow cytometric analysis. ${ }^{*} \mathrm{P}<0.05,37^{\circ} \mathrm{C}$ vs. $43^{\circ} \mathrm{C}$ in SW480-8HhP+Fludara.

calculate $\mathrm{IC}_{50}$ values for each line, which was calculated as the drug concentration that inhibited growth by $50 \%$. When incubated with different concentrations of Fludara (ranging from 0 to $2 \mu \mathrm{g} / \mathrm{ml}$ ), parental, CON- and $8 \mathrm{HhP}$-infected cells were resistant at $37^{\circ} \mathrm{C}$. In contrast, $\mathrm{SW} 480-8 \mathrm{HhP}$ cells were susceptible to Fludara at $43^{\circ} \mathrm{C}\left(\mathrm{IC}_{50}=0.02924\right)$, lower than SW480-8HhP cells at $37^{\circ} \mathrm{C}\left(\mathrm{IC}_{50}=0.07618\right)$, SW480 and SW480-CON at $37^{\circ} \mathrm{C}$ or $43^{\circ} \mathrm{C}$ (Fig. 2A). Conversely, hTERTnegative MKN74 cells showed a higher $\mathrm{IC}_{50}$ at $37^{\circ} \mathrm{C}$ or $43^{\circ} \mathrm{C}$ (Fig. 2A). At a concentration of $0.05 \mu \mathrm{g} / \mathrm{ml}$ Fludara, the sensitivity of the infected SW480 cells was time-dependent (Fig. 2B). The data showed that hyperthermia significantly reduced SW480-8HhP cell viability compared with either SW480 or SW480-CON cells, under both normal and heated conditions. However, this result was not replicated in MKN74-8HhP cells (Fig. 2B), because MKN74 cells do not express hTERT, and thus, the lentiviral vector did not induce ePNP expression in these cells (Fig. 2B). These results indicated that ePNP sensitized cancer cells to Fludara only in hTERT-high expressing SW480-8HhP cells, especially under heated conditions.
High level of bystander effect to Fludara. In the absence of ePNP-positive cells, the growth of parental cells was not affected even when the concentration of Fludara was $0.1 \mu \mathrm{g} / \mathrm{ml}$. At a concentration of $0.05 \mu \mathrm{g} / \mathrm{ml}$ Fludara, a significant bystander effect could be detected, even at a very low proportion (5\%, Fig. 2C) of ePNP-positive SW480-8HhP cells at $43^{\circ} \mathrm{C}$. We detected a weaker bystander effect at the same proportion of ePNP-positive SW480-8HhP cells at $37^{\circ} \mathrm{C}$. Furthermore, no obvious bystander effect was detected in MKN74-CON and MKN74-8HhP cells at $43^{\circ} \mathrm{C}$ or $37^{\circ} \mathrm{C}$. These results indicated that a significant bystander effect was found in SW480-8HhP cells under heated conditions (Fig. 2C).

Effects of Fludara on SW480 apoptosis. To further elaborate the causes of cell growth inhibition, we detected apoptosis rates by flow cytometry. The results showed that $0.05 \mu \mathrm{g} / \mathrm{ml}$ Fludara treatment increased the rate of spontaneous apoptosis in the infected cells compared with control cells (Fig. 2D) in hTERT-high expressing SW480 cells, but not in MKN74 cells. The greatest increase in the number of apoptotic cells 

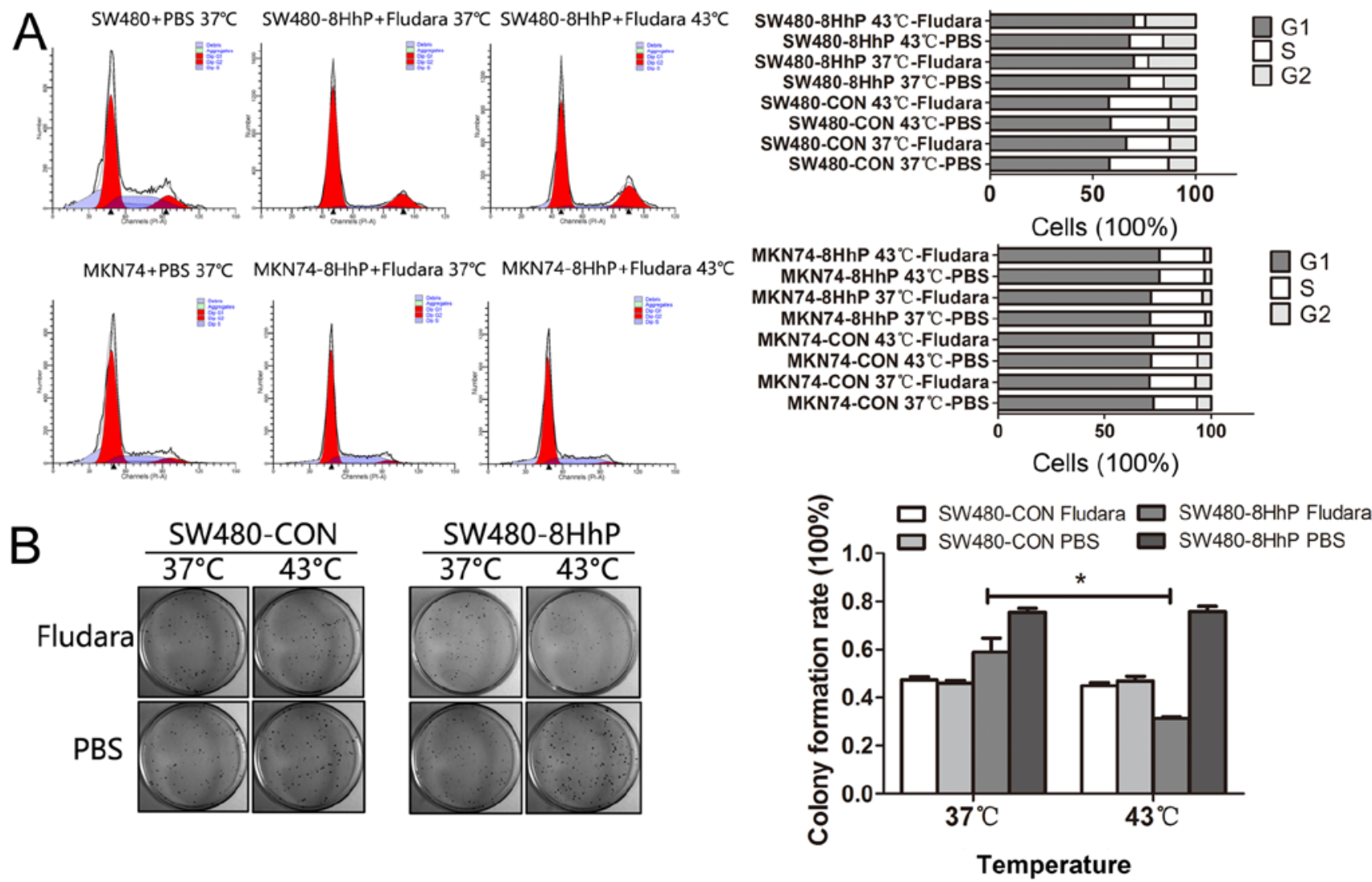

Figure 3. Cytotoxicity of the suicide system ePNP/Fludara regulated by the synthetic 8HSEs-hTERT promoter. (A) Cell cycle distribution of SW480, MKN74 and the corresponding infected cells to Fludara at $37^{\circ} \mathrm{C}$ or $43^{\circ} \mathrm{C}$ by flow cytometric analysis. (B) Colony formation rates of SW480, MKN74 and the corresponding infected cells to Fludara at $37^{\circ} \mathrm{C}$ or $43^{\circ} \mathrm{C}$. ${ }^{\circ} \mathrm{P}<0.05,37^{\circ} \mathrm{C}$ vs. $43^{\circ} \mathrm{C}$ in $\mathrm{SW} 480-8 \mathrm{HhP}+$ Fludara.

was in $\mathrm{SW} 480-8 \mathrm{HhP}$, and the ratio was $48.9 \%$ at $43^{\circ} \mathrm{C}$ and $42.1 \%$ at $37^{\circ} \mathrm{C}$. These results indicated that the suicide system ePNP/Fludara inhibited cell proliferation by causing apoptosis, and the 8HSEs-hTERT promoter could enhance the effect only in hTERT-high expressing cells under heated conditions.

Effects of Fludara on SW480 cell cycle profiles. To explore the mechanism whereby the suicide system ePNP/Fludara inhibited cell proliferation, we studied the effect on the cell cycle. The targeted cells were treated with $0.05 \mu \mathrm{g} / \mathrm{ml}$ Fludara at $43^{\circ} \mathrm{C}$ or $37^{\circ} \mathrm{C}$, and cellular DNA content was measured by flow cytometry. The data obtained from these studies demonstrated that ePNP/Fludara induces a $\mathrm{G}_{2}$ cell cycle arrest only in SW480-8HhP cells (Fig. 3A). At $72 \mathrm{~h}$, flow cytometric analysis of SW480-8HhP cells showed an $\sim 2$-fold increase in the percentage of cells in $\mathrm{G}_{2}-\mathrm{M}$ phase $(22.89 \%)$ compared with cells infected with $\mathrm{CON}$ vector $(12.32 \%$; Fig. 3A) under normal conditions. The addition of hyperthermia produced an additional increase in $\mathrm{G}_{2}-\mathrm{M}$ cells to $24.5 \%$ in $\mathrm{SW} 480-8 \mathrm{HhP}$ cells. Conversely, few differences were observed between MKN74-CON and MKN74-8HhP cells at $43^{\circ} \mathrm{C}$ or $37^{\circ} \mathrm{C}$. These results indicated that the suicide system ePNP/Fludara inhibited cell proliferation by causing $\mathrm{a}_{2}$ cell cycle arrest, and the 8HSEs-hTERT promoter could enhance the effect only in hTERT-high expressing cells under heated conditions.

Effects of Fludara on SW480 colony formation. We next evaluated the colony formation ability of SW480 cells expressing ePNP. After exposure to $37^{\circ} \mathrm{C}$ or $43^{\circ} \mathrm{C}$ treatments, SW480 cells were treated with Fludara. The Fludara plus $43^{\circ} \mathrm{C}$ treatment significantly reduced SW480-8HhP colony formation $(\mathrm{P}<0.05$, Fig. $3 \mathrm{~B})$. However, $43^{\circ} \mathrm{C}$ treatment exhibited no effect in all other cells when combined with either PBS or control vector. The $43^{\circ} \mathrm{C}$ treatment caused a significant colony formation decrease only in SW480-8HhP cells after exposure to Fludara when compared with PBS, control vector, $37^{\circ} \mathrm{C}$ or MKN74 cells (data not shown). These results indicated that the suicide system ePNP/Fludara inhibited colony formation, and the 8HSEs-hTERT promoter could enhance the effect only in hTERT-high expressing cells under heated conditions, demonstrating cancer- and heat-specificity.

Effects of in vitro ePNP/Fludara on Bax, caspase-3, p53 and cyclin D1 expression. To investigate the molecular events associated with ePNP/Fludara-mediated cell cycle arrest and apoptosis, we assessed whether recombinant $8 \mathrm{HhP}-$ regulated ePNP/Fludara could affect the expression of Bax, Bcl-2, caspase-3, p53, Fas and cyclin D1 under heated conditions in vitro. A significantly variable upregulation of the apoptotic proteins Bax, caspase-3 and p53, and downregulation of the anti-apoptotic protein Bcl-2 were achieved when ePNP/Fludara was included in SW480 cells (Figs. 4 and 5, ${ }^{*} \mathrm{P}<0.05, \mathrm{P}<0.05$ ). Conversely, significant changes in expression by ePNP/Fludara did not occur in the hTERT-negative MKN74 cells. Only Cyclin D1 protein was not detected in SW480, SW480-CON and SW480-8HhP cells. These results indicated that changes 


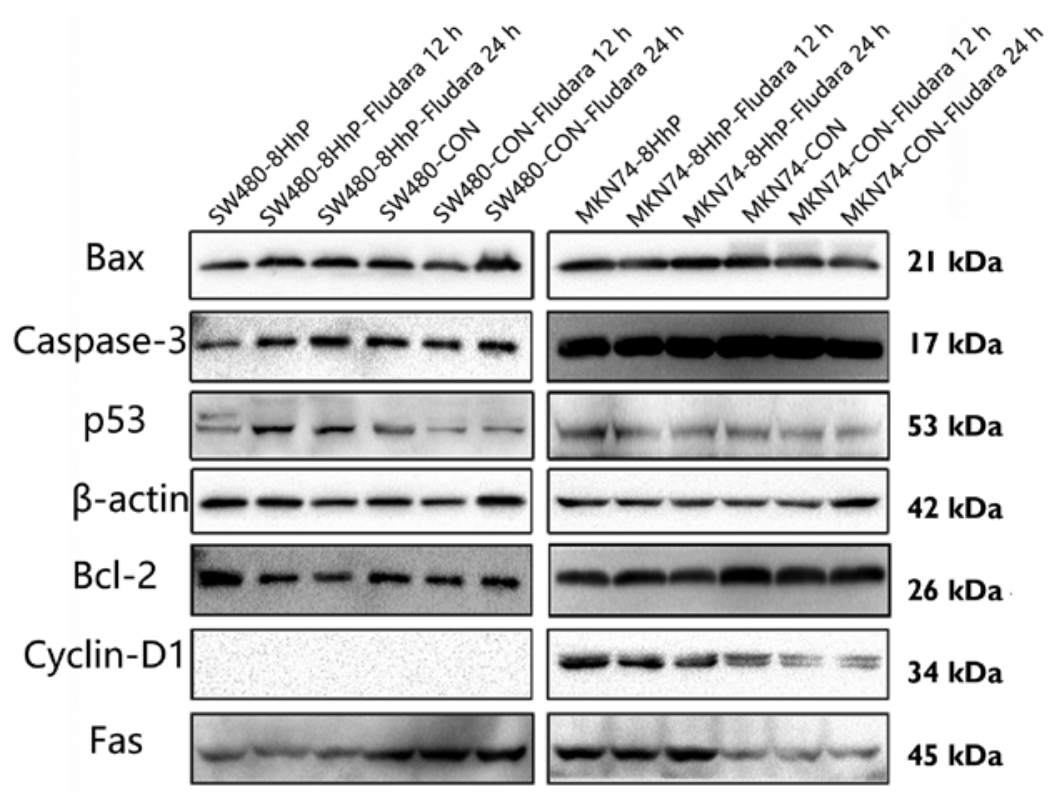

Figure 4. Effects of the suicide system ePNP/Fludara on the regulation of Bax, caspase-3, p53 and cyclin D1 proteins in vitro. Western blot analysis of Bax, Bcl-2, caspase-3, p53, Fas and cyclin D1 expression in SW480 and MKN74 cells.
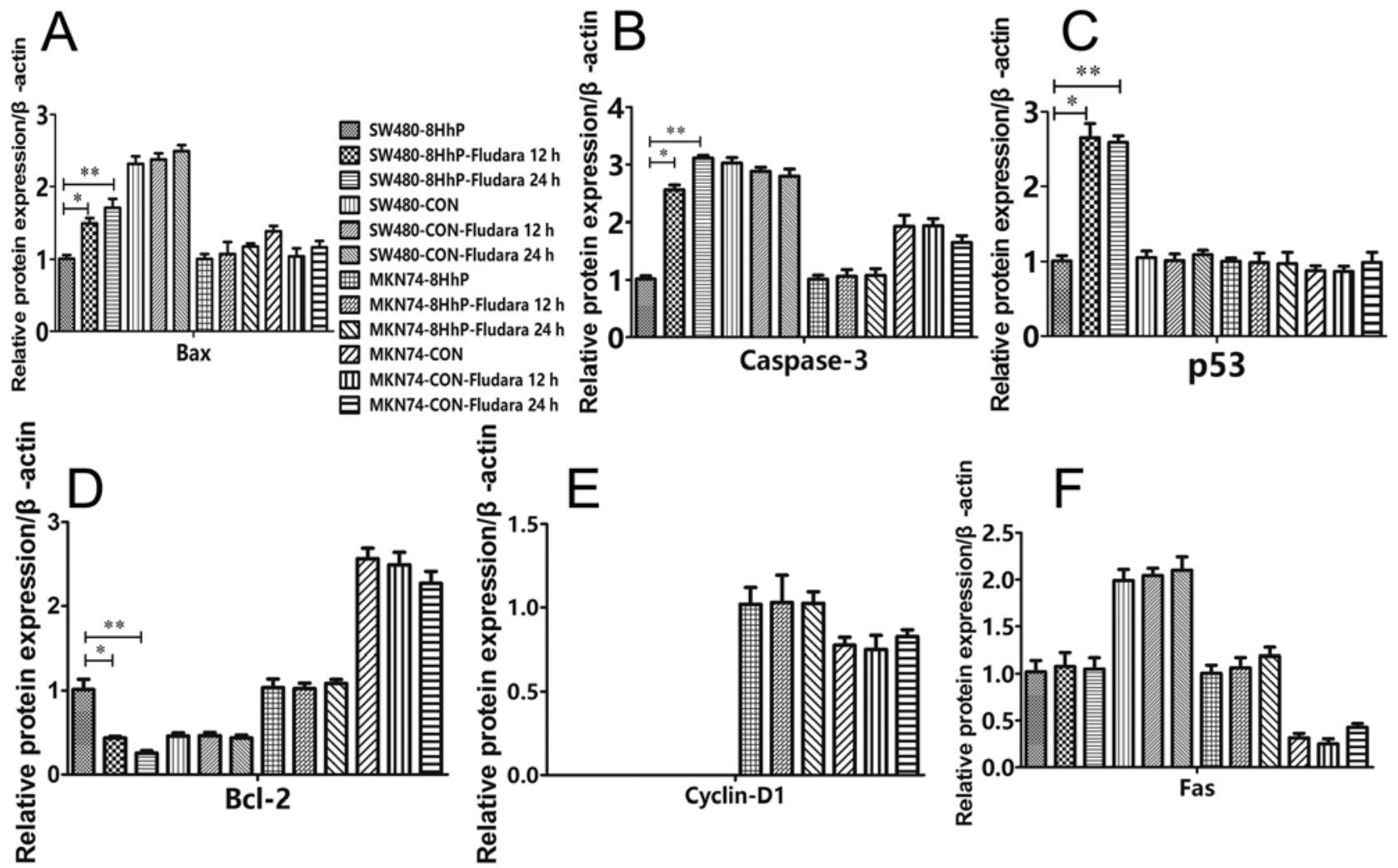

Figure 5. Integrated optical densities were measured to evaluate (A) Bax, (B) caspase-3, (C) p53, (D) Bcl-2, (E) cyclin D1 and (F) Fas proteins expression relative to $\beta$-actin. "P<0.05, SW480-8HhP vs. SW480-8HhP+Fludara $12 \mathrm{~h}$; ** P<0.05, SW480-8HhP vs. SW480-8HhP+Fludara 24 h.

in the expression of apoptosis-regulating proteins was occurring in the ePNP/Fludara treated cells.

Effects of lentiviral-mediated gene therapy on a mouse xenograft model. SW480 and MKN74 cells were subcutaneously implanted in BALB/c nude mice. Mice were monitored every two days for tumor growth and after 8 days, xenograft tumors formed and grew to $50-100 \mathrm{~mm}^{3}$. Then, we intratumorally injected lentiviruses $\left(1 \times 10^{8} \mathrm{pfu}\right)$ in $100 \mu \mathrm{l}$ of serum-free medium at three sites per xenograft tumor and repeated the injections on day 4. Two weeks after the second virus injection, mice were sacrificed and xenograft tumors were collected, 

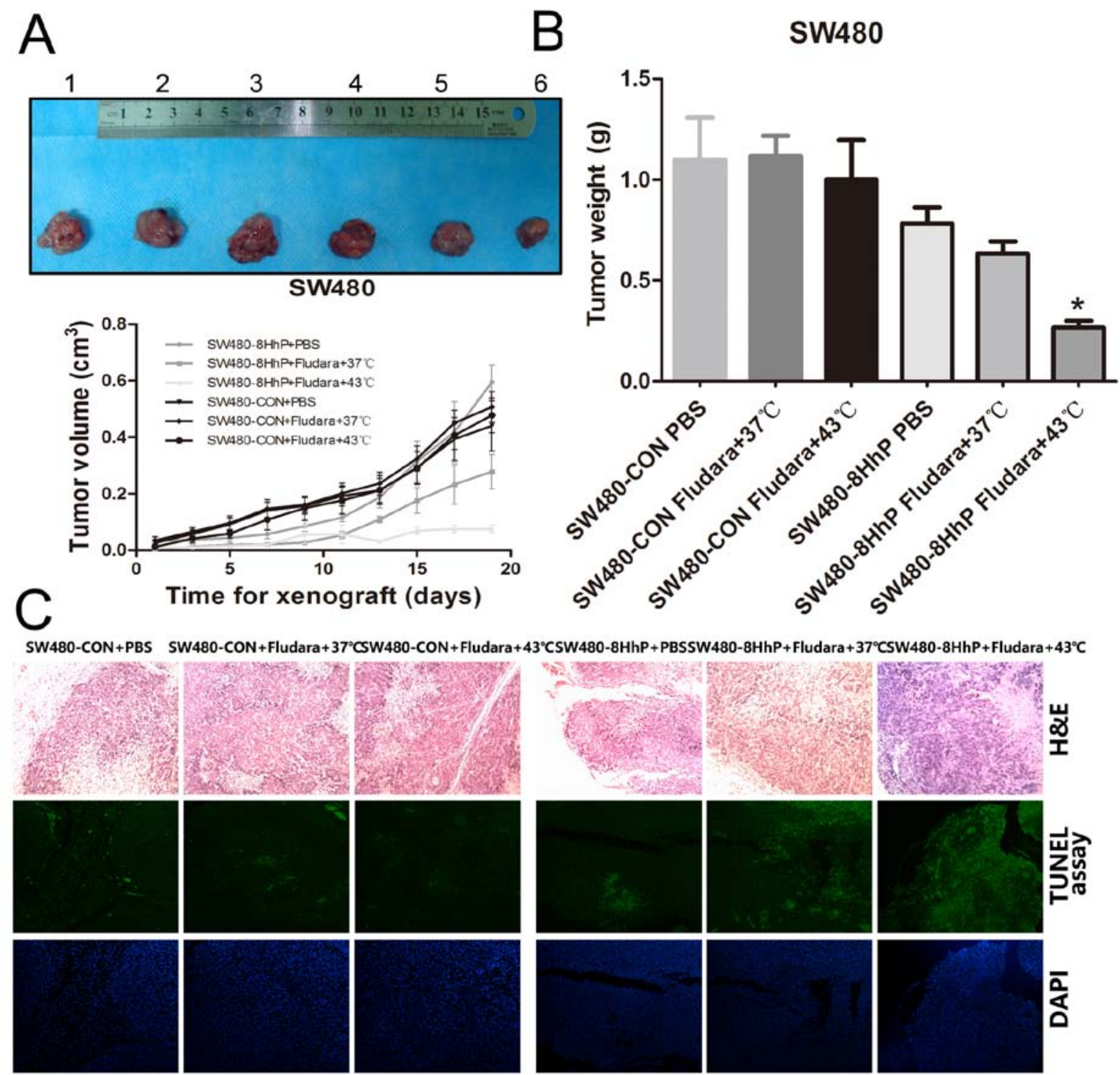

Figure 6. In vivo antitumor effects of the $8 \mathrm{HhP}$ recombinant lentivirus in SW480 cells at $37^{\circ} \mathrm{C}$ or $43^{\circ} \mathrm{C}$. (A) Xenograft growth curves of SW480 cells infected by the $8 \mathrm{HhP}$ or $\mathrm{CON}$ recombinant lentiviruses and treated with Fludara at $37^{\circ} \mathrm{C}$ or $43^{\circ} \mathrm{C}$. (B) Xenograft weights at the end of the experiment. ${ }^{\prime \prime} \mathrm{P}<0.05$, SW480-8HhP+Fludara $+43^{\circ} \mathrm{C}$ vs. SW480-8HhP+Fludara $+37^{\circ} \mathrm{C}$. (C) TUNEL analysis revealing xenograft apoptosis of SW480 cells infected by the $8 \mathrm{HhP}$ or $\mathrm{CON}$ recombinant lentiviruses and treated with Fludara at $37^{\circ} \mathrm{C}$ or $43^{\circ} \mathrm{C}$.

measured and photographed. Compared with PBS at $37^{\circ} \mathrm{C}$ and the control lentivirus groups, the size and weight of the tumors were significantly lower in the SW480-8HhP+Fludara $+43^{\circ} \mathrm{C}$ group $(\mathrm{P}<0.05$; Fig. 6B). Conversely, this it did not occur in MKN74 cells; the size and weight of tumors showed no significant differences in any of the MKN74 groups (Fig. 7B). TUNEL assay data also showed that the suicide system ePNP/ Fludara regulated by the recombinant $8 \mathrm{HhP}$ lentivirus induced more apoptosis in SW480 xenograft tumors (Fig. 6C). No obvious differences in apoptosis were found in the MKN74 xenograft tumors (Fig. 7C). These results demonstrated that ePNP/Fludara induced apoptosis and the recombinant lentivirus $8 \mathrm{HhP}$ had tumor- and heat-specificity in vivo.

\section{Discussion}

In this study, we explored rational strategies for combining an ePNP/Fludara system controlled by a novel chimeric promoter with hyperthermia. We cloned the suicide gene ePNP into a recombinant lentiviral vector to express the ePNP gene with high efficiency and enhanced target specificity in tumor cells. When the prodrug Fludara was added, massive cytotoxicity was induced. Both in vitro and in vivo experiments confirmed the efficiency and specificity of this system.

We found several advantages to the 8HSE-hTERT promoter system for cancer therapy. First, the combination of ePNP/ Fludara gene therapy with hyperthermia presents possible therapeutic advantages in the treatment of solid malignancies. Second, combining gene therapy and hyperthermia has the potential to overcome many of the limitations of hyperthermia alone. Third, 8HSEs elements can enhance the activity of hTERT promoter under heated conditions but do not dampen its specificity to cancer cells. HSEs have been demonstrated to be necessary for the heat inducibility of the HSP70B promoter and have been widely used in gene therapy as an inducible tumor-specific promoter (16). The precise mechanism of this 


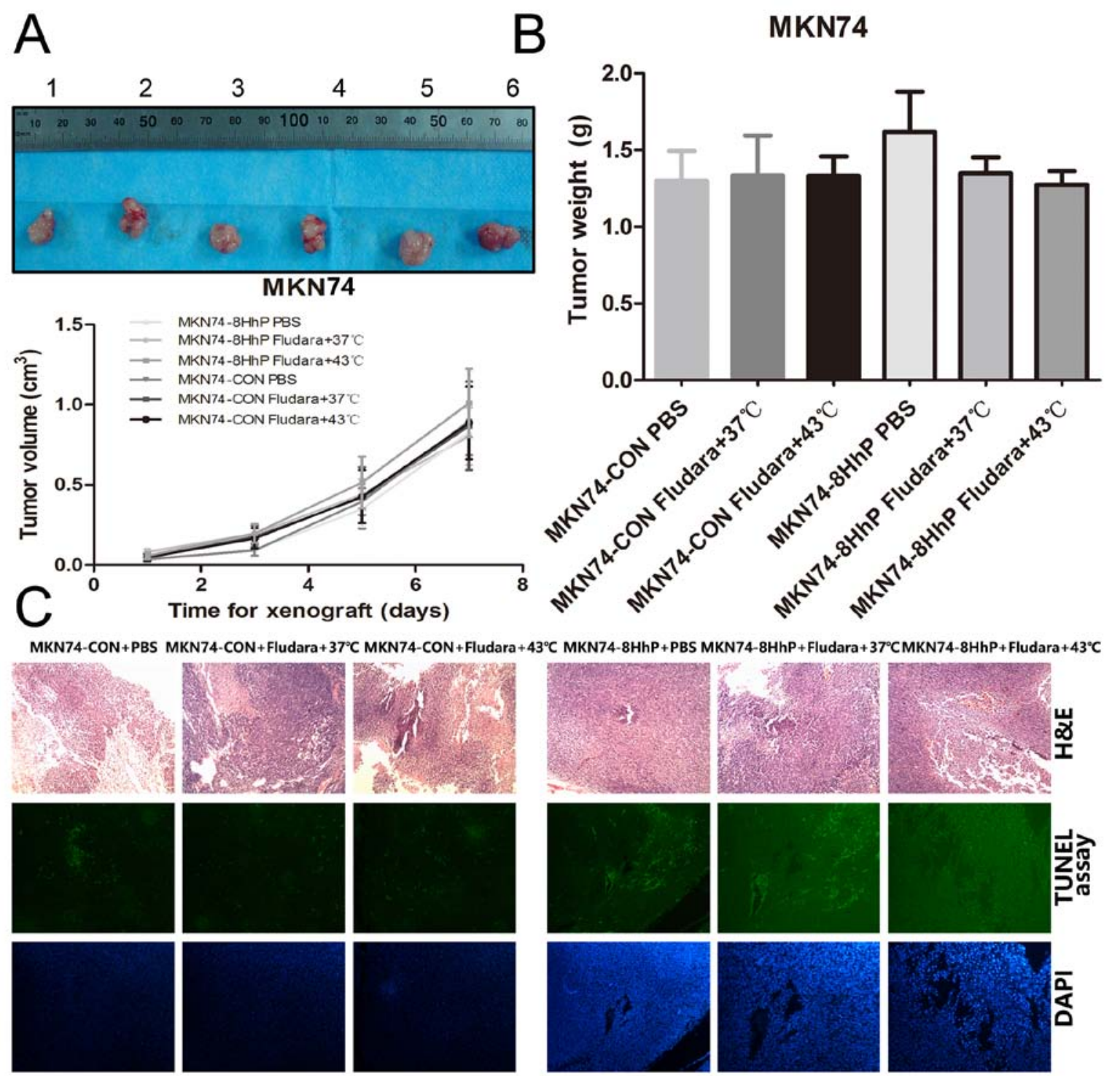

Figure 7. In vivo antitumor effects of the $8 \mathrm{HhP}$ recombinant lentivirus in $\mathrm{MKN} 74$ cells at $37^{\circ} \mathrm{C}$ or $43^{\circ} \mathrm{C}$. (A) Xenograft growth curves of MKN74 cells infected by the $8 \mathrm{HhP}$ or CON recombinant lentiviruses and treated with Fludara at $37^{\circ} \mathrm{C}$ or $43^{\circ} \mathrm{C}$. (B) Xenograft weights at the end of the experiment. (C) TUNEL analysis revealing xenograft apoptosis of MKN74 cells infected by the $8 \mathrm{HhP}$ or CON recombinant lentiviruses and treated with Fludara at $37^{\circ} \mathrm{C}$ or $43^{\circ} \mathrm{C}$.

response and the transcription factors that interact with HSE elements have yet to be elucidated. However, it is known that complexes of transcription factors and accessory proteins, including heat-shock inducible transcription factor (heat shock factor 1, HSF1), promote gene expression by binding to HSE motifs (17). In this study, we demonstrated that eight consecutive HSEs improve the induction response to hyperthermia, which may be explained simply because eight target sequences provide efficient binding sites for HSF1.

The PNP/Fludara system also has several advantages for treating colorectal cancer. First, PNP converts Fludara into a highly cytotoxic metabolite F-dAe, which is an inhibitor of both ribonucleoside reductase and DNA polymerase-A and effectively kills both dividing and non-dividing cells (18). By contrast, the common suicide system HSV-TK/GCV can kill dividing cells but not senescent or slowly-dividing cells (19). Second, overexpression of ePNP can activate the prodrug Fludara and kill almost entire populations of tumor cells, even when as few as 5\% of the cells express the ePNP gene (20). Hong et al showed that human glioma tumors in mice were inhibited by adenoviral delivery of ePNP followed by systemic treatment with the clinically approved compound Fludara in different proportions of ePNP expressing cells (21). In this study, we observed activity of the PNP/Fludara system in SW480 cells when only 5\% of the cells expressed the ePNP gene. Furthermore, the bystander effect of the PNP/Fludara system was mostly absent in hTERT-negative MKN74 cells. This indicated that the bystander effects exhibited dependence on both the level of prodrug administered and ePNP expression in vitro (Fig. 2). Third, fludarabine has been studied extensively, and pharmacokinetics of the agent in animal models are well defined. Conversely, MeP-dR, another prodrug of ePNP, has to be chemically synthesized in laboratories because there is no readily available source. Finally, analysis of the mechanisms of cell death of hepatocellular carcinoma expressing the suicide gene showed that PNP/Fludara induced apoptosis through p53 
accumulation in p53-positive cells compared to p53-negative cells (22). Our results indicated that PNP/Fludara-induced apoptosis, might depend not only on p53 accumulation, but also on other factors, such as Bax and caspase-3. The precise apoptotic mechanisms induced by PNP/Fludara remain to be determined. Furthermore, we detected a $\mathrm{G}_{2} / \mathrm{M}$ arrest in PNP/Fludara-treated cells, as shown previously, suggesting the PNP/Fludara suicide system might induce irreversible DNA damage (23). Together, this study revealed that the mechanism by which PNP/Fludara inhibits the proliferation of SW480-8HhP cells might be related to inducing apoptosis and $\mathrm{G}_{2} / \mathrm{M}$ arrest under heated conditions.

The synergistic effect of ePNP and Fludara, bringing greater efficacy than the two alone, has important clinical significance; in particular, the ability to use low doses of Fludara should translate to reduced side effects and clinical improvements in quality of life. This is particularly relevant for patients with ePNP who had previously been or who were undergoing chemotherapy with Fludara. The reduction in the therapeutic dose of ePNP also decreases the amount of Fludara required for each patient. The data obtained in this study warrant further confirmation in vivo and in vitro. It has been reported that synergy between ePNP and docetaxel against prostate cancer cells led to a decrease in tumor load, both in the prostate and at distant sites in immunocompetent mice (24). However, interactions between PNP and docetaxel are not yet fully understood (25). A better understanding of these interactions will help design new studies in patients who have experienced pre-existing treatment.

To understand the interaction between PNP and Fludara, molecular studies were performed. Apoptosis has been shown to play a significant role in the cell death triggered by some suicide systems (26). The most effective apoptotic stimulus occurred when PNP interacted with Fludara, which was reflected in the cell killing observed in our studies. Pro- or anti-apoptotic proteins and caspases that regulate apoptosis have been observed in several suicide system treatments (27). Overall, the pro-apoptotic proteins Bax, cleaved caspase-3 or -9 were upregulated the and anti-apoptotic protein, Bcl-2 was downregulated when suicide systems were implemented (28). Strong expression of both caspase- 3 and Bcl-2 in responses to the suicide system suggests that pathways involving caspases and the Bcl-2 family may be active in these systems (29). This is the first study to identify changes in apoptosis-related proteins in response to PNP/Fludara in SW480 cells. However, our results do not rule out that PNP/Fludara may be acting through numerous processes ultimately leading to an upregulation of pro-apoptotic or a downregulation of anti-apoptotic proteins (30).

To investigate in vivo our in vitro observation that the 8HSEs-hTERTp-ePNP/Fludara system was capable of inducing heat- and tumor-specific killing effects, we tested tumor growth following heat treatment in a mouse xenograft model, injected with a heat-inducible lentiviral vector. In addition to tumor-specific killing effects, 8HSEs-hTERTp-ePNP/ Fludara system exhibited optimal tumor xenograft growth inhibition under heated conditions. Supporting these observations, TUNEL assays showed that the 8HSEs-hTERTp-ePNP/ Fludara system induced obvious apoptosis following hyperthermia in SW480 xenografts. These results suggest that the
8HSEs-hTERTp-ePNP/Fludara system might be a promising method of modulating gene expression during treatment by clinical hyperthermia.

In conclusion, we have demonstrated that the 8HSEshTERTp-ePNP/Fludara suicide system efficiently kills hTERT-expressing tumor cells in vivo and in vitro. Inclusion of 8HSEs-hTERTp in the recombinant lentivirus vector significantly improved the antitumor effects and specificity to heat treatment of the ePNP/Fludara system. Furthermore, we have demonstrated that the 8HSEs-hTERTp-ePNP/Fludara suicide system induced antitumor effects by promoting apoptosis and a $\mathrm{G}_{2}$ arrest. Our study suggests that by combining hyperthermia with gene therapy, the 8HSEs-hTERTp-ePNP/Fludara system, may serve as a powerful strategy for tumor gene therapy under hyperthermia.

\section{Acknowledgements}

This study was supported by a grant from the National Natural Science Foundation of China (grant serial nos. 81101874 and 81172362), the Science and Technology Project of Shaanxi Province (grant serial no. 2016SF-015), the Coordinative and Innovative Plan Projects of the Science and Technology Program in Shaanxi Province (grant serial nos. 2013KTCQ03-08).

\section{References}

1. Sorscher EJ, Peng S, Bebok Z, Allan PW, Bennett LL Jr and Parker WB: Tumor cell bystander killing in colonic carcinoma utilizing the Escherichia coli DeoD gene to generate toxic purines. Gene Ther 1: 233-238, 1994.

2. Afshar S, Olafsen T, Wu AM and Morrison SL: Characterization of an engineered human purine nucleoside phosphorylase fused to an anti-her2/neu single chain Fv for use in ADEPT. J Exp Clin Cancer Res 28: 147, 2009.

3. Parker WB, Allan PW, Shaddix SC, Rose LM, Speegle HF, Gillespie GY and Bennett LL Jr: Metabolism and metabolic actions of 6-methylpurine and 2-fluoroadenine in human cells. Biochem Pharmacol 55: 1673-1681, 1998.

4. van der Zee J and González DG: Regional hyperthermia for rectal cancer. Lancet 356: 772, 2000.

5. Sherar M, Liu FF, Pintilie M, Levin W, Hunt J, Hill R, Hand J, Vernon C, van Rhoon G, van der Zee J, et al: Relationship between thermal dose and outcome in thermoradiotherapy treatments for superficial recurrences of breast cancer: Data from a phase III trial. Int J Radiat Oncol Biol Phys 39: 371-380, 1997.

6. Wust P, Hildebrandt B, Sreenivasa G, Rau B, Gellermann J, Riess H, Felix R and Schlag PM: Hyperthermia in combined treatment of cancer. Lancet Oncol 3: 487-497, 2002.

7. Morimoto RI, Sarge KD and Abravaya K: Transcriptional regulation of heat shock genes. A paradigm for inducible genomic responses. J Biol Chem 267: 21987-21990, 1992.

8. Brade AM, Ngo D, Szmitko P, Li PX, Liu FF and Klamut HJ: Heat-directed gene targeting of adenoviral vectors to tumor cells. Cancer Gene Ther 7: 1566-1574, 2000.

9. Hildebrandt B, Wust P, Rau B, Schlag P and Riess H: Regional hyperthermia for rectal cancer. Lancet 356: 771-772, 2000.

10. Wang X, Zhou P, Sun X, Wei G, Zhang L, Wang H, Yao J, Jia $\mathrm{P}$ and Zheng J: Modification of the hTERT promoter by heat shock elements enhances the efficiency and specificity of cancer targeted gene therapy. Int J Hyperthermia 32: 244-253, 2016.

11. Horikawa I, Chiang YJ, Patterson T, Feigenbaum L, Leem SH, Michishita E, Larionov V, Hodes RJ and Barrett JC: Differential cis-regulation of human versus mouse TERT gene expression in vivo: Identification of a human-specific repressive element. Proc Natl Acad Sci USA 102: 18437-18442, 2005.

12. Cunniff NF and Morgan WD: Analysis of heat shock element recognition by saturation mutagenesis of the human HSP70.1 gene promoter. J Biol Chem 268: 8317-8324, 1993. 
13. Mosmann T: Rapid colorimetric assay for cellular growth and survival: Application to proliferation and cytotoxicity assays. J Immunol Methods 65: 55-63, 1983.

14. Parker WB, Allan PW, Hassan AEA, Secrist JA III, Sorscher EJ and Waud WR: Antitumor activity of 2-fluoro-2'-deoxyadenosine against tumors that express Escherichia coli purine nucleoside phosphorylase. Cancer Gene Ther 10: 23-29, 2003.

15. Pan Z, Sun X, Shan H, Wang N, Wang J, Ren J, Feng S, Xie L, Lu C, Yuan Y, et al: MicroRNA-101 inhibited postinfarct cardiac fibrosis and improved left ventricular compliance via the FBJ osteosarcoma oncogene/transforming growth factor- $\beta 1$ pathway. Circulation 126: 840-850, 2012.

16. Mocna M, Granja C, Leroy C and Stekl I: Hyperthermia in oncology. AIP Conf Proc 958: 256-257, 2007.

17. Akerfelt M, Morimoto RI and Sistonen L: Heat shock factors: Integrators of cell stress, development and lifespan. Nat Rev Mol Cell Biol 11: 545-555, 2010.

18. Zhang Y, Parker WB, Sorscher EJ and Ealick SE: PNP anticancer gene therapy. Curr Top Med Chem 5: 1259-1274, 2005.

19. van Dillen IJ, Mulder NH, Vaalburg W, de Vries EF and Hospers GA: Influence of the bystander effect on HSV-tk/GCV gene therapy. A review. Curr Gene Ther 2: 307-322, 2002.

20. Chaudhary K, Ting LM, Kim K and Roos DS: Toxoplasma gondi purine nucleoside phosphorylase biochemical characterization, inhibitor profiles, and comparison with the Plasmodium falciparum ortholog. J Biol Chem 281: 25652-25658, 2006.

21. Hong JS, Waud WR, Levasseur DN, Townes TM, Wen H, McPherson SA, Moore BA, Bebok Z, Allan PW, Secrist JA III, et al: Excellent in vivo bystander activity of fludarabine phosphate against human glioma xenografts that express the Escherichia coli purine nucleoside phosphorylase gene. Cancer Res 64: 6610-6615, 2004.

22. Krohne TU, Shankara S, Geissler M, Roberts BL, Wands JR, Blum HE and Mohr L: Mechanisms of cell death induced by suicide genes encoding purine nucleoside phosphorylase and thymidine kinase in human hepatocellular carcinoma cells in vitro. Hepatology 34: 511-518, 2001.
23. Singh PP, Joshi S, Russell PJ, Nair S and Khatri A: Purine Nucleoside Phosphorylase mediated molecular chemotherapy and conventional chemotherapy: A tangible union against chemoresistant cancer. BMC Cancer 11: 368, 2011.

24. Wang XY, Martiniello-Wilks R, Shaw JM, Ho T, Coulston N, Cooke-Yarborough C, Molloy PL, Cameron F, Moghaddam M, Lockett TJ, et al: Preclinical evaluation of a prostate-targeted genedirected enzyme prodrug therapy delivered by ovine atadenovirus. Gene Ther 11: 1559-1567, 2004.

25. Pan D, Jin L and Zhang X: The latest advances of experimental research on targeted gene therapy for prostate cancer. ChineseGerman J Clin Oncol 12: 546-550, 2013.

26. Barese CN, Felizardo TC, Sellers SE, Keyvanfar K, Di Stasi A Metzger ME, Krouse AE, Donahue RE, Spencer DM and Dunbar CE: Regulated apoptosis of genetically modified hematopoietic stem and progenitor cells via an inducible caspase-9 suicide gene in rhesus macaques. Stem Cells 33: 91-100, 2015.

27. Carlotti F, Zaldumbide A, Martin P, Boulukos KE, Hoeben RC and Pognonec P: Development of an inducible suicide gene system based on human caspase 8 . Cancer Gene Ther 12: 627-639, 2005.

28. Chen Y, Shi S, Wang H, Li N, Su J, Chou G and Wang S: A Homogeneous polysaccharide from fructus Schisandra chinensis (Turz.) baill induces mitochondrial apoptosis through the Hsp90/ AKT signalling pathway in HepG2 cells. Int J Mol Sci 17: 1015, 2016.

29. Cali U, Cavkaytar S, Sirvan L and Danisman N: Placental apoptosis in preeclampsia, intrauterine growth retardation, and HELLP syndrome: An immunohistochemical study with caspase-3 and bcl-2. Clin Exp Obstet Gynecol 40: 45-48, 2013.

30. Karjoo Z, Chen X and Hatefi A: Progress and problems with the use of suicide genes for targeted cancer therapy. Adv Drug Deliv Rev 99A: 113-128, 2016. 